\title{
Charles Mason Comments on Candidates for Iowa's Governorship, 1845
}

\author{
introduction by HOMER L. CALKIN
}

With James K. Polk's inauguration as president in 1845, the Democratic party returned to power after a four-year Whig administration. Many government officials appointed by President John Tyler were to be replaced. Among those soon to be out of office was John Chambers, who had been named governor of Iowa Territory in 1841. At least seven or eight candidates were seeking his position during the summer of 1845. Each man customarily attempted to get outstanding and well-known members of his party to write letters of recommendation to the president or some other influential official in Washington, D.C.

Charles Mason, chief justice of the Supreme Court of Iowa Territory, was highly respected among Democrats. More than one aspiring candidate wanted his support. Instead of recommending any one individual, Mason commented on five of them in a letter to James Shields of Illinois, commissioner of the General Land Office. Polk had appointed Shields commissioner in 1845, and from this strategic position Shields frequently channeled to Polk information about potential office-holders.

In two letters dated October 26, 1845 Mason gave his opinion of four aspirants to the governorship, but declined to write about Joseph Williams, his associate on the Supreme Court. Mason did comment on Robert Lucas, territorial governor from 1838 to 1841; Shepherd Leffler, an 1839 representative in the 
Legislative Assembly of Iowa and delegate to the first constitutional convention in 1844; Enos Lowe, who practiced medicine in Burlington and was a delegate to the 1844 convention; and James Clarke, who had been a newspaper man in Burlington in 1837. In 1839 President Martin Van Buren had appointed Clarke secretary of the territory, a position he held until 1841. He also was the son-in-law of Henry Dodge, governor of Wisconsin Territory.

Shields transmitted Mason's two letters to Polk on November 3. Clarke was commissioned as third governor of the Territory of Iowa on November 18. He held the position until December 2, 1846 when he gave his farewell message to the first General Assembly of the state of Iowa. Clarke died on July 28, 1850 of cholera after spending his last twelve days at Charles Mason's home.

Mason's letters, which are included here, give some candid insights into Iowa politics in 1845 and document the type of information that may have affected the appointment of a governor of Iowa. Both letters are available in Applications and Recommendations for Public Office, Department of State, Record Group 59, National Archives and Records Service, Washington, D.C. The first letter, written on the morning of October 26 , is from the Charles Mason folder, and the second, written later the same day, is from the James Clarke folder.

(Confidential)

\section{Burlington Iowa October 26th 1845}

Sir

Within the last few days I have learnt that renewed efforts are about to be made to affect a change in the office of Governor of this Territory. I have also been applied to by the friends of two or three of the candidates for this successorship for recommendatory letters which in some instances were requested to be directed to you. This will explain the reason for the liberty I am now taking. I have declined taking any open part for or against any of the candidates but have concluded to make to you sir as 
candid a statement in relation to their respective claims as I am capable of doing in order to aid you as far as I can in your recommendation to the President on this subject.

Of Judge Williams I do not intend to write. He is my associate on the Bench of the Supreme Court \& I should feel a delicacy in saying any thing for or against him. This I suppose is also rendered unnecessary as I am informed upon good authority that he will not be likely to receive the appointment at any rate.

Governor Lucas desires the office \& I have sometimes hoped the President would reappoint him. He is a self willed obstinate old man-may almost be said to be in his dotage-\& he is regarded as not altogether staunch in politics. But he is conversant with the duties of the office \& would be able to discharge them creditably from habit if not by the exercise of reason. He would not faulter [sic] in his political orthodoxy during the present Presidential term \& by the termination of it death or old age will have closed his political career. The younger aspirants for station would prefer him to one of their more immediate competitors \& the consequences of an improper selection would be less disastrous. Besides he was ejected from office rather unceremoniously by the late dynasty \& a great many of our people would be gratified by his restoration as a species of merited retaliation.

Mr Leffler has recently become a candidate for that office. He is a gentleman of high respectability. Intellectually \& morally he is unexceptionable \& is besides possessed of a great degree of popularity. But there are many of us who doubt the genuineness of his political principles \& believe that when the gales shall blow adversely he will be found drifting with-rather than assisting in beating against them. But laying aside this matter of opinion which is founded upon so many circumstances that they cannot now be related I will merely state two or three more substantial \& tangible objections.

In the first place he labored most industriously to defeat the nomination of Gen Dodge prior to the late election in order that he might be himself selected. Personally \& by his emissaries he succeeded in creating a noisy if not a formidable opposition which for a while threatened defeat to the party.

To him more than to any other man is due the fact that we are 


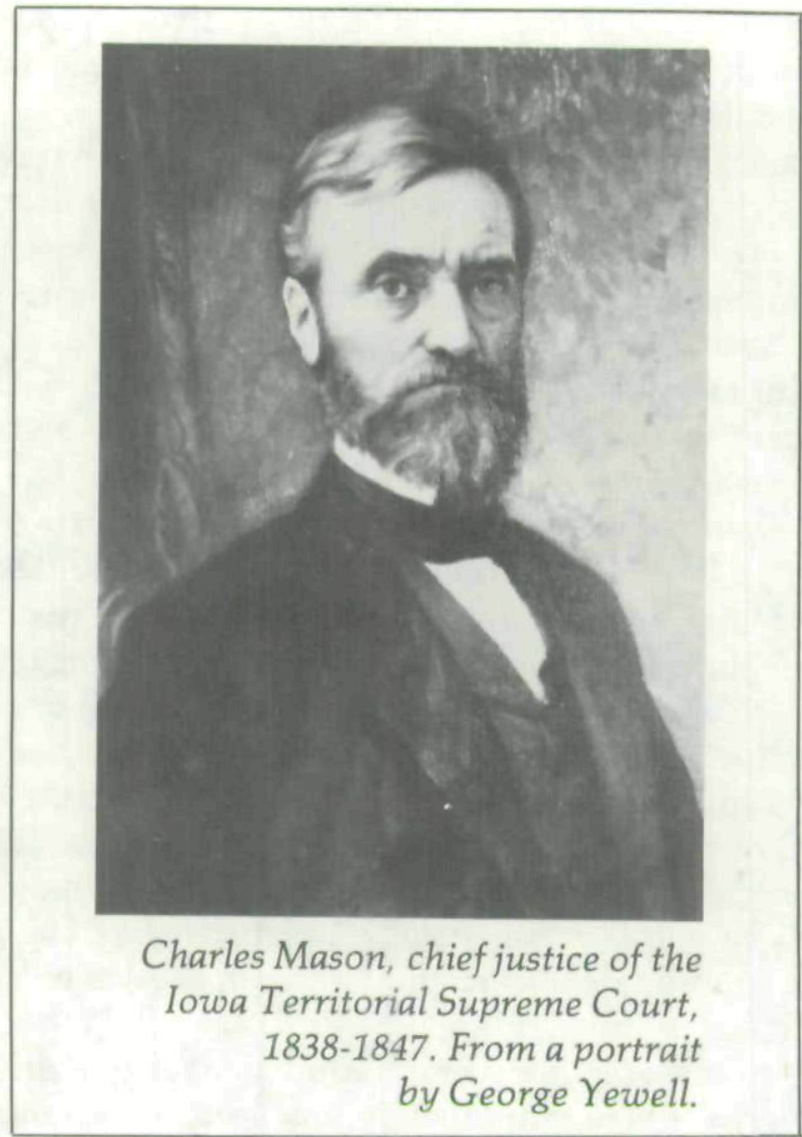

not to be represented in both branches of the next congress as a sovereign state. Dodge had taken grounds in favor of the constitution with the congressional boundaries \& therefore his enemies, including Leffler at the head of a wing of the democratic army were opposed to it. This county in which Leffler resides can give a democratic majority of near 100 . It gave more than 500 against the constitution last spring all owing as I believe to the fact just mentioned. The entire majority against the constitution at that time was about 900 .

Besides he is specially bent upon having a mammoth state. I have heard him declare that he was in favor of remaining a Territory for ten years rather than come in with boundaries less than those fixed in our constitution. Now for my part I prefer a 
smaller state. I would rather have the 17 th meridian prolonged till it reached the Mississippi river on the north than any other possible western boundary-so clearly do I conceive it for the interest of the west to have states formed of a moderate size \& for our interest to have a state limited to the waters of the Mississippi. Above all I wish to get into the Union upon almost any terms \& do not wish to be thwarted in this by the influence of a Governor obstinately standing out in favor of inordinate dimensions.

Mr James Clarke is also aspiring to that station \& to him there is but one objection which is worth mentioning. He is the son in law of Governor Dodge \& here as elsewhere there is a jealousy in regard to family advancement when carried to any great extent. I doubt not but his appointment would be the signal of a most furious onslaught upon his brother in law Gen [Augustus] Dodge \& one which would not be without effect. In fact prior to the late election the charge was made by the whig press that this appointment was held in abeyance until after the election for the purpose of having Mr Clarke appointed. This was contradicted by Gen Dodge's friends upon the authority of the Burlington Gazette of which Mr Clarke is the Editor. Now it will not be sufficient to satisfy the public that Gen Dodge takes no part in procuring Mr. Clarke's appointment. Such a charge will be made anew \& believed by many \& at all events it will be said that Dodge has at least negatively procured the appointment by refusing to recommend any one else where it is generally understood that such recommendation would have been conclusive. This clamor will not be confined to the whigs but will proceed from the disappointed candidates \& their friends as well as from those who are already disguised enemies or lukewarm friends in consequence of like disappointment in regard to other offices. I regard Dodge's success as coincident with that of the democratic party in this Territory \& whatever would tend to place that success in jeopardy, as a political calamity. This is the length \& breadth of this objection to Mr Clarke of the weight of which you are as competent to judge as we are. Personally I should prefer his appointment to that of any other whose names I have already mentioned.

Dr Enos Lowe of Burlington has been spoken of by many here 
as a proper person for that office. I know not whether any effort has been or will be made to secure his appointment but I think he possesses all the qualifications of any of the gentlemen above mentioned with none of the objections. On this subject I refer you to Gen Dodge. He was appointed Register of the Land office by Mr Van Buren \& was one of the earliest victims of whig proscription. I think his appointment would be preferable to that of any other man in the Territory.

Yours truly

Charles Mason

Hon James Shields

\section{Sir}

I wrote you at length this morning in reference to the different candidates for the office of Governor of this Territory. Since that time I have received some information which has induced me to add a few lines to what was then said.

I have no doubt but the staunch democracy of the Territory are in favor of the appointment of Mr Clarke in preference to Mr Leffler. In my letter of this morning I alluded to the opposition of a fraction of the democratic party to Gen Dodge of which fraction Mr Leffler was the leader. The present effort to make him Governor is part of the same attempt to overthrow Gen Dodge in the Territory. I stated to you that the only valid objection I saw to Mr Clarke's appointment was the unfavorable influence such an appointment might possibly have upon the future prospect of Gen Dodge. I am free however to state that so far as this object is concerned I have no doubt but Mr Leffler's appointment would have a much more prejudicial influence than that of $\mathrm{Mr}$ Clarke. I have no doubt but that the great cry of relationship is confined principally to a few disappointed aspirants \& to the whig party. The people in general pay very little attention to this matter \& care very little for it. 
Copyright of Annals of Iowa is the property of State of Iowa, by \& through the State Historical Society of Iowa and its content may not be copied or emailed to multiple sites or posted to a listserv without the copyright holder's express written permission. However, users may print, download, or email articles for individual use. 